\title{
Hybrid Sandwich Particleboard Made with Sugarcane, Pínus Taeda Thermally Treated and Malva Fibre from Amazon
}

\author{
Marcio Rogerio Silva ${ }^{a}$, Roberto Vasconcelos Pinheiro ${ }^{b}$, André Luis Christoforo ${ }^{c}$, \\ Tulio Hallak Panzera ${ }^{d *}$, Francisco Antonio Rocco Lahr
}

\author{
${ }^{a}$ Faculdade de Etnodiversidade, Universidade Federal do Pará - UFPA, Campus Universitário de \\ Altamira, R. Cel. José Porfirio, 2515, São Sebastião, 68372-040, Altamira, PA, Brazil \\ ${ }^{b}$ Faculdade de Ciência Exatas e Tecnológica - FACET, Universidade do Estado de Mato Grosso - UNEMAT, \\ Campus de Universitário de Sinop, Av. dos Ingás, 3001, 78555-000, Jardim Imperial, Sinop, MT, Brazil \\ ${ }^{c}$ Centro de Inovação e Tecnologia em Compósitos - CIT C , Departamento de Engenharia Civil, \\ Universidade Federal de São Carlos - UFSCar, Campus São Carlos, Rodovia Washington Luís, Km \\ 235, s/n - Jardim Guanabara, 13565-905, São Carlos, SP, Brazil \\ ${ }^{d}$ Centro de Inovação e Tecnologia em Compósitos - CIT C, Departamento de Engenharia Mecânica, \\ Universidade Federal de São João del-Rei - UFSJ, Campus Santo Antônio, Praça Frei Orlando, 170, \\ 36307-352, São João del-Rei, MG, Brazil \\ eDepartamento de Engenharia de Estruturas - SET, Escola de Engenharia de São Carlos - EESC, \\ Universidade de São Paulo - USP, Av. Trabalhador São-carlense, 400, 13566-590, São Carlos, SP, \\ Brazil
}

Received: August 09, 2017; Revised: October 24, 2017; Accepted: November 10, 2017

\begin{abstract}
A multilayer particleboard panels, consisted of sugarcane bagasse reinforced composite as core material and hybrid composites made with Pinus taeda particles and Malva fibres as facing materials, were designed and evaluated in this work. Tukey test was used to identify the effect of the facing material, considering different combinations of Pinus taeda particles and Malva fibres, on the bulk density, thickness swelling, flexural strength, flexural stiffness and X-ray densitometry. A spray-up process was used to spread castor oil based polyurethane resin upon the dispersive phases followed by a hot compaction at $100^{\circ} \mathrm{C}$. The particleboards were classified as medium density panels in accordance to the Brazilian, American and Canadian Standards. All treatments reached the minimum strength except for elastic modulus. Tukey test demonstrated the flexural strength and modulus responses for all treatments were statistically similar. Hybrid particleboard consisted of $75 \%$ of Pinus taeda wood and $25 \%$ of Malva fibres revealed a promising sustainable material for furniture industries, combining strength, low-cost and lower thickness swelling values.
\end{abstract}

Keywords: mechanical and physical properties, $X$-ray densitometry, multilayer particleboards, sugarcane bagasse, Pinus taeda and Malva fibre

\section{Introduction}

In recent years, the building and furniture industries have demanded particleboard panels with high durability and sustainable characteristics ${ }^{1}$. The panels have been produced by pressing lignocellulosic materials, leading to high mechanical properties and specific strength/stiffness ${ }^{2}$. The Brazilian particleboard industries have been used a high amount of reforested wood, such as Pinus and Eucalyptus ${ }^{3,4}$. The demand for wood products has been rising considerably year by year, which promotes an increase in reforestation areas with fast-growing species ${ }^{5}$. In general, fifty percent of the particleboard industries use softwood as main raw material, and the others use more than one wood specie in the production lines ${ }^{6,7}$. Commonly, reforested woods do not achieve the structural requirements for particleboard panels design. This situation is considered an economical

*e-mail: panzera@ufsj.edu.br and environmental concern, in which the scarcity of raw material can promote its valorisation. Instead of increasing the reforestation areas, alternative materials have been considered to replace wood without loss of quality ${ }^{8}$.

The generation of lignocellulosic wastes from the Brazilian agricultural industries, such as corncob, rice husk, coffee husk, peanuts husk, coconut husk, castor bean husk, sugarcane bagasse, among others, has been considered promising raw materials and recycling route to meet growing particleboard market demand. In addition, a reduction in the use of reforested wood can also contribute to make the products cheaper ${ }^{6}$.

The sugarcane bagasse is a solid waste that remains after grinding process in the ethyl alcohol production. The generation of bagasse depends on the sugarcane species. In general, $30 \%$ of bagasse is extracted in a ton of sugarcane processed. The most part of this bagasse is burned in a 
boiler for electrical generation and the other part is used to produce pulp, paper and board. However, the burning of sugarcane bagasse releases pollutants into the atmosphere. The sugarcane waste can be considered underexplored in Brazil $^{9-11}$. The main components of sugarcane bagasse are $32-50 \%$ cellulose, $19-25 \%$ hemicelluloses, $23-32 \%$ lignin, $2 \%$ ashes, $46 \%$ fibres and $50 \%$ humidity ${ }^{12}$. The chemical composition of sugarcane bagasse shows similarity with softwoods. Bagasse is a lignocellulosic waste with a potential use in the production of particleboards ${ }^{13}$.

The use of natural fibres has been an alternative as low impact income, strategy of environmental conservation and fast biodegradability. Malva and Juta are Amazonian fibres commonly used to produce paper, dress room, string, tissue, carpets and sacks for packing of products like coffee, cor and cocoa. In order to use these fibres as reinforcements in composite production, several surface treatments have been proposed in the literature to enhance their interaction with the matrix phase $\mathrm{e}^{14-17}$.

Thermal treatments performed in wood can change its chemical components in the cell wall and extractives. In general, oxygen and hydrogen content are reduced in the wood, since hemicelluloses are more susceptible to degrade in low temperature, due to low molecular weight, branched and amorphous structure with different and substituted monomeric units. Deacetylation reactions lead to the formation of acetic acid, in which it is a catalyst in the depolymerisation, while dehydration leads to the formation of furfural and hidroxymethylfurfural. The crystallinity cellulose increases with amorphous cellulose degradation, therefore, the accessibility in hydroxyls groups to the water molecule decreases. At the same time, a thermal treatment produces dehydration reactions and cellulose oxidation, which promote the lignin condensation ${ }^{14-17}$.

Panels made with sugarcane bagasse and eucalyptus wood, impregnated with phenol formaldehyde and urea formaldehyde resin at 6,9 and $12 \mathrm{wt} \%$ levels, have been evaluated by Mendes et al. ${ }^{6}$. Thickness swelling, water absorption, density, flexural strength and stiffness properties have been assessed. The urea resin has led to similar or superior results than phenol formaldehyde. Mean stiffness values approximately at $1000 \mathrm{MPa}$ did not fit the range from 1750 and $2450 \mathrm{MPa}$ recommended by Canadian Standard CS - 236-66.

Hot-pressed MDF panels made with pine with different percentage of phenol formaldehyde $(6,9$ and $12 \%)$ have been evaluated via internal bond, flexural strength and stiffness. The panels were thermally treated at 160,170 and $180^{\circ} \mathrm{C}$. The findings did not reveal significant changes in mechanical properties when compared to the pristine condition. Moreover, the internal bond results were higher than the pristine condition ${ }^{18}$.

Panels made with eucalyptus fibres with different percentage of sugarcane bagasse $(25,50,75$ e 100\%) and impregnated with urea formaldehyde have been investigated by Belini et al. ${ }^{19}$. The increase amount of sugarcane bagasse has led to reduced flexural strength and stiffness. At $100 \%$ level of sugarcane bagasse the results did not attend the minimum requirements described in the Brazilian Standard ABNT NBR $15316-3^{20}$. The mean flexural strength and modulus values found for panels made with $100 \%$ of sugarcane bagasse were 14.3 and $1736 \mathrm{MPa}$, respectively. In contrast, the internal bond $\left(0.55 \mathrm{~N} . \mathrm{mm}^{-2}\right)$ and thickness swelling (12\%) findings attended the minimum values recommended by NBR 15316-320.

Iwakiri et al. ${ }^{21}$ have evaluated the physical and mechanical properties of particleboard panels manufactured with wood particles from Sequoia sempervirens and Pinus taeda combined with urea-formaldehyde resin (UF), using different mixing ratios. The findings achieved for internal bond, modulus of elasticity (MOE) and modulus of rupture (MOR) under static bending have met the minimum requirements of British Standard BS312:2003 in all treatments, revealing that Sequoia sempervirens has great potential for particleboard production $^{21}$.

In order to combine the mechanical performance of Pinus taeda and Sugarcane bagasse, hot-pressed hybrid sandwich particleboard panels were investigated in this work. The sugarcane bagasse composite was used as core material, while hybrid composites, made with Pinus taeda thermally treated and Malva fibres, were used as facing materials. The properties such as, bulk density, thickness swelling, flexural strength and stiffness, combined with scanning electron microscopy (SEM), energy dispersive spectroscopy (EDS) and X-ray densitometry analysis were used to characterize the panels.

\section{Material and Methods}

Pinus taeda wood particles were thermally treated following the methodology reported by Silva ${ }^{22}$. A density of $550 \mathrm{~kg} \cdot \mathrm{m}^{-3}$ and a wood moisture content of $12 \%( \pm 2)$ were initially measured. The thermal treatment was conducted in a metal container built in an electrical furnace. Wood pieces of $560 \times 160 \times 60 \mathrm{~mm}^{3}$ in dimensions were placed inside the container. Two iron bars of $10 \mathrm{~mm}$ in diameter was placed between the wood timbers to promote the gas circulation. The thermal degradation in wood components occurs faster in oxygen atmosphere ${ }^{23}$. For this reason, the thermal treatment was performed in a nitrogen atmosphere, in which a constant flux was injected to avoid wood oxidation. Seven wood timbers were placed inside the container. The temperature levels were measured by seven thermocouples (type K), in which three of them were placed inside the first wood timber, two inside the sixth wood timber, one inside the electrical furnace and the other inside the container. This setup was used not only to control the furnace temperature but also to verify the heat inside the wood timber. The 
thermal treatment was carried out at $200^{\circ} \mathrm{C}( \pm 5)$ with an initial heating rate at $2.5^{\circ} \mathrm{C} \cdot \mathrm{min}^{-1}$ until $100^{\circ} \mathrm{C}$, and $0.033^{\circ} \mathrm{C}$. $\min ^{-1}$ until the final temperature.

The multilayer particleboard panels were constituted of lignocellulosic particles, such as the sugarcane bagasse, Pinus taeda particles and Malva fibres. Firstly, the flakes were ground in a knife mill being pre-classified in a particle size range from $2.8 \mathrm{~mm}$ to $5 \mathrm{~mm}$ in diameter. Subsequently, a sieving process was used to classify the sugarcane in a particle size range between $2.38 \mathrm{~mm}$ and $0.50 \mathrm{~mm}$, the Pinus taeda between $1.41 \mathrm{~mm}$ and $0.50 \mathrm{~mm}$, and the Malva fibres between $4.77 \mathrm{~mm}$ and $3.36 \mathrm{~mm}$.

The panels were designed to have a density of $0.7 \mathrm{~g} . \mathrm{cm}^{-3}$ in order to achieve a medium density particleboard based on the Brazilian Standard ABNT NBR $14810^{24}$. The core material was made with sugarcane bagasse considering $6 \mathrm{~mm}$ in thickness. The facing material is a hybrid composite consisted of treated Pinus taeda particles and Malva fibres with $2 \mathrm{~mm}$ in thickness for each side (see Figure 1). Five different fibre configurations (Table 1) were investigated as follows: Treatment A with $100 \%$ of Pinus taeda (100P), Treatment B with $75 \%$ of Pinus taeda and $25 \%$ of Malva fibres (75P/25M), Treatment $C$ with $50 \%$ of Pinus taeda and Malva fibres $(50 \mathrm{P} / 50 \mathrm{M})$, Treatment D with $25 \%$ of Pinus taeda and $75 \%$ of Malva fibres $(25 \mathrm{P} / 75 \mathrm{M})$, and Treatment E with $100 \%$ of Malva fibres (100M).

The response-variables were: flexural strength $\left(\mathrm{MOR}_{\mathrm{F}}\right)$, flexural modulus $\left(\mathrm{MOE}_{\mathrm{F}}\right)$, density $(\rho)$ and thickness swelling (TS). Eight samples were fabricated for each experimental condition. The effects of the factors were identified via Analysis of Variance (ANOVA) and Tukey test at 95\% confidence interval ${ }^{11}$. The statistical analyses were performed using Minitab v.16.

Castor oil based polyurethane resin was used as matrix phase being impregnated via spray process and mechanically mixed. The resin was supplied by Plural Química Company (São Carlos-Brazil). The spray impregnation allowed to combine castor oil and 4,4'-diphenylmethane di-isocyanate oil (MDI) separately (Figure 2a). Subsequently, the particles

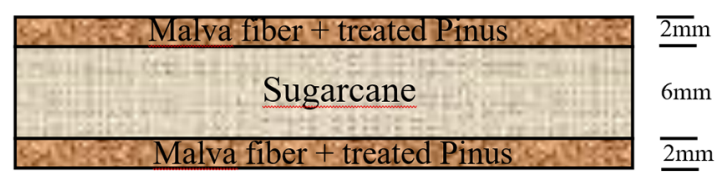

Figure 1. Particleboard manufacturing scheme.

Table 1. Facing material investigation: experimental setup

\begin{tabular}{ccc}
\hline Treatments & Pinus Taeda (\%) & Malva Fibres (\%) \\
\hline A & 100 & 0 \\
B & 75 & 25 \\
C & 50 & 50 \\
D & 25 & 75 \\
E & 0 & 100 \\
\hline
\end{tabular}

were mixed by using a Hobart mixer for 5 minutes (Figure 2b). The material was spread within a mould (Figure 2c), and hot-pressed at $4 \mathrm{MPa}$ for $10 \mathrm{~min}$ at $100^{\circ} \mathrm{C}$ (Figure $2 \mathrm{~d}$ ). This type of resin was chosen to avoid the emission of formaldehyde as reported in the literature ${ }^{25}$. The panels were demoulded after $72 \mathrm{~h}$ according to the polymer curing time. The physical and mechanical properties were obtained in accordance to the Brazilian Standard ABNT NBR 14810:226.

X-ray densitometry (QTRS-01X) manufactured by Quintek Measurement Systems was used to measure the density of multilayer particleboard samples (Figure $2 \mathrm{f}$ ). The $\mathrm{X}$-ray values across the samples were converted to apparent density by the software QMS. Microstructural analyses of the composites were conducted using a Scanning Electron Microscopy HITACHI (TM-3000) with an electron beam acceleration of $15 \mathrm{kV}$ associated with the Energy Dispersive Spectroscopy (EDS).

\section{Results}

Table 2 shows the mean values and Tukey test which enables to compare the means by groups, for bulk density $(\rho)$, thickness swelling (TS), flexural strength $\left(\mathrm{MOR}_{\mathrm{F}}\right)$ and stiffness $\left(\mathrm{MOE}_{\mathrm{F}}\right)$ properties. Same letters imply treatments with equivalent values.

Based on Tukey test there is no difference in bulk density values, showing a similar letter group (a) for all treatments. The mean bulk density data varied from 0.68 to $0.73 \mathrm{~g} . \mathrm{cm}^{-3}$ which classify the panels as "medium density" based on the

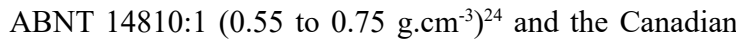
$(\mathrm{CS} 236-66)^{27}$ and American (ANSI A208:1) ${ }^{28}$ (0.6 and 0.8 g. $\left.\mathrm{cm}^{-3}\right)$ standards.

The use of thermally treated wood was motivated by improving the dimensional stability of multilayer particleboard panels. Hemicelluloses are considered the most hydrophilic component of wood and the most thermally sensitive. This is the first component to degrade being revealed by the consumption of hydroxyl groups from the water molecules. For this reason, reductions in equilibrium moisture content and thickness swelling have been reported in the literature ${ }^{15,29,30}$. In order to avoid any environment effect mainly on the core material, the peripherical sides of
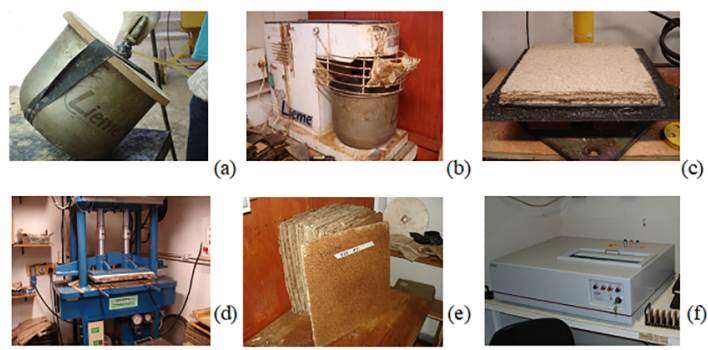

Figure 2. Spray impregnation (a), mechanical mixing (b), particleboard mould (c), uniaxial hot compaction (d), panels after processing (e) and X-ray densitometry tree scanner (f). 
Table 2. Physical and mechanical properties of particleboards

\begin{tabular}{|c|c|c|c|c|c|c|c|c|c|c|}
\hline \multirow[b]{2}{*}{ Treatments } & \multicolumn{2}{|c|}{$\rho\left(\mathrm{g} . \mathrm{cm}^{-3}\right)$} & \multicolumn{2}{|c|}{ TS $(\%)-2 h$} & \multicolumn{2}{|c|}{ TS (\%) - 24h } & \multicolumn{2}{|c|}{$\mathrm{MOR}_{\mathrm{F}}(\mathrm{MPa})$} & \multicolumn{2}{|c|}{$\operatorname{MOE}_{\mathrm{F}}(\mathrm{MPa})$} \\
\hline & Mean \pm SD & Tukey & $\begin{array}{c}\text { Mean } \pm \\
\text { SD }\end{array}$ & Tukey & $\begin{array}{c}\text { Mean } \pm \\
\text { SD }\end{array}$ & Tukey & $\begin{array}{c}\text { Mean } \pm \\
\text { SD }\end{array}$ & Tukey & Mean \pm SD & Tukey \\
\hline $\mathrm{A}(100 \mathrm{P})$ & $0.71 \pm 0.07$ & $\mathrm{a}$ & $1.6 \pm 0.2$ & $\mathrm{a}$ & $6.4 \pm 1.2$ & a & $11 \pm 3$ & $\mathrm{a}$ & $1188 \pm 404$ & $\mathrm{a}$ \\
\hline $\mathrm{B}(75 \mathrm{P} / 25 \mathrm{M})$ & $0.70 \pm 0.09$ & $\mathrm{a}$ & $2.4 \pm 0.7$ & $a b$ & $7.6 \pm 0.7$ & $\mathrm{a}$ & $11 \pm 4$ & $\mathrm{a}$ & $1089 \pm 472$ & $\mathrm{a}$ \\
\hline $\mathrm{C}(50 \mathrm{P} / 50 \mathrm{M})$ & $0.68 \pm 0.08$ & a & $3.8 \pm 0.8$ & $\mathrm{bc}$ & $11.6 \pm 1.6$ & $\mathrm{~b}$ & $11 \pm 4$ & $\mathrm{a}$ & $1106 \pm 462$ & $\mathrm{a}$ \\
\hline $\mathrm{D}(25 \mathrm{P} / 75 \mathrm{M})$ & $0.73 \pm 0.11$ & $\mathrm{a}$ & $4.9 \pm 1.7$ & $\mathrm{~cd}$ & $12.6 \pm 1.7$ & $\mathrm{~b}$ & $11 \pm 4$ & $\mathrm{a}$ & $1165 \pm 452$ & $\mathrm{a}$ \\
\hline $\mathrm{E}(100 \mathrm{M})$ & $0.72 \pm 0.08$ & $\mathrm{a}$ & $5.8 \pm 1.8$ & d & $16.8 \pm 2.8$ & $\mathrm{c}$ & $12 \pm 4$ & $\mathrm{a}$ & $1285 \pm 396$ & $\mathrm{a}$ \\
\hline
\end{tabular}

Values are mean \pm standard deviation (SD). Means followed by the same letter are not significant (Tukey $\alpha=5 \%$ ).

the samples were painted with epoxy polymer. Treatment A, made with $100 \%$ of treated Pinus taeda in outer layer, achieved the lowest thickness swelling response (group a). In contrast, a higher thickness swelling was reached when $100 \%$ of Malva fibres was considered (group d). Malva fibres absorb more water, for this reason the thickness swelling (TS) was higher than those treatments with a large amount of Pinus. The Brazilian Standard ABNT NBR 14810:226 recommends no more than $8 \%$ for thickness swelling with $2 \mathrm{~h}$; and no more than $14 \%$ at $24 \mathrm{~h}$ for internal use in dry conditions. Although the statistical analyses show different means for thickness swelling at $2 \mathrm{~h}$, all treatments attend the standard limit, except for Treatment $\mathrm{E}$ which reaches 16.8 (group c). Fiorelli et al. ${ }^{31}$ have investigated the thickness swelling of sugarcane particleboards containing 5 and 8 $\mathrm{mm}$ fibre lengths impregnated with castor oil resin. The lowest swelling of $20 \%$ has been achieved for $8 \mathrm{~mm}$ fibres. This behaviour has been attributed to the particle packing effect which affects the composite microstructure and pore sizes. Filho ${ }^{8}$ has investigated a sugarcane particleboard reinforced with Pinus or Eucalyptus particles considering a weight fraction of $50 \%$. These panels were produced with $9 \%$ of formaldehyde urea and formaldehyde melamine. The thickness swelling values ranged from 7 to $26 \%$ for $2 \mathrm{~h}$, and from 26 to $36 \%$ for $24 \mathrm{~h}$. The thermal treatment of Pinus taeda particle was considered the main responsible for the improved thickness swelling. Murata, Watanabe and Nakano ${ }^{32}$ have studied the fibre saturation point (FSP) for Spruce wood thermally treated. The FSP has started to decrease above $150^{\circ} \mathrm{C}$.

The minimum values for flexural strength (MOR) and modulus (MOE) considered by the Brazilian ${ }^{26}$, Canadian $^{27}$ and American ${ }^{28}$ standards are: 11.0 and $1800 \mathrm{MPa}, 11.2$ and $2450 \mathrm{MPa}$, and 11.0 and $1725 \mathrm{MPa}$, respectively. All treatments are in accordance to the standard requirements with respect to MOR values. The highest MOR ( 12MPa) was achieved by Treatment E consisted of $100 \%$ of Malva fibres. In contrast, no treatment could attend the MOE limits required by these standards. It is emphasized the use of a different hardener can enhance the stiffness of the castor oil based polyurethane matrix phase, consequently, being able to attend the structural requirements in future investigations. Mendes et al. ${ }^{6}$ have studied sugarcane particleboards combined with eucalyptus wood. The MOR results ( $12-15 \mathrm{MPa})$ have reached the minimum requirements found in the normative documents. Particleboards made only with eucalyptus wood achieved higher MOE values (up to 47\%) than the Brazilian standard requirements $(\sim 1.7-2.7 \mathrm{GPa})^{30}$. Belini et al. ${ }^{19}$ have investigated particleboard panels reinforced with sugarcane bagasse and eucalyptus fibres impregnated with formaldehyde urea. The increase in sugarcane bagasse fraction (at 75\%) has led to reduced MOR $(\sim 22.9 \mathrm{MPa})$ and MOE $(\sim 2.6 \mathrm{GPa})$ properties. In addition, particleboards produced only with sugarcane bagasse did not reach the minimum values recommended by the Brazilian Standard ${ }^{20}$. In the present work, the statistical analyses (see Table 2) showed there is no difference among treatments regarding to flexural strength and stiffness properties.

Figure 3 shows the Scanning Electron Microscopy (SEM) images obtained in backscattering mode for Treatments A-E. All images were obtained at $\times 50$ of magnification, except for Treatment $\mathrm{D}$ which was analysed in a higher magnification $(\times 200)$ to observe the impregnation process. Figure $3 \mathrm{a}$ and Figure $3 \mathrm{e}$ show the microstructure of particleboards consisted of treated Pinus (Treatment A) and Malva fibres (Treatment E), respectively. Figures $3 \mathrm{~b}$ and $3 \mathrm{~d}$ show Treatments $\mathrm{B}$ and $\mathrm{D}$, respectively, revealing the increasing amount of Malva fibres from Treatment B to D. Figure 3 f shows Treatment D at $\times 200$ of magnification revealing a uniform matrix phase distribution along the dispersive phases. Figure $3 \mathrm{f}$ shows Pinus particles in the right side and Malva fibres in the left side of the image. Bertolini ${ }^{33}$ and Nascimento ${ }^{34}$ have reported that the mechanical properties of particleboards depend mainly on the interaction of the phases, in which the amount and the distribution of the matrix phase in the system is extremely significant, providing higher durability and low water absorption.

The white spots presented in Figure $3 f$ were identified via Energy Dispersive Spectroscopy (EDS). Figure 4 shows the EDS micrographs of sugarcane bagasse (a) and Malva fibre (b) which reveals the presence of silicon elements, being attributed to silicon dioxide $\left(\mathrm{SiO}_{2}\right)$. Similar results 

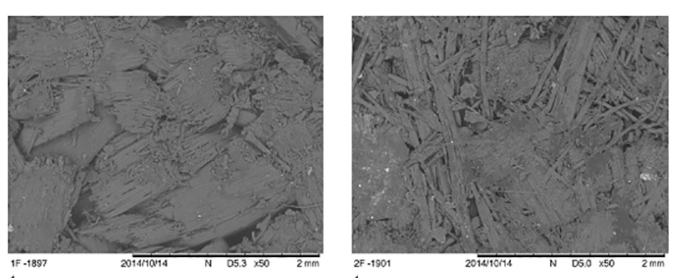

(a)

(b)
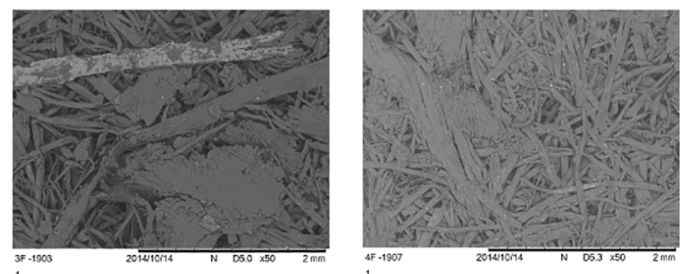

(c)
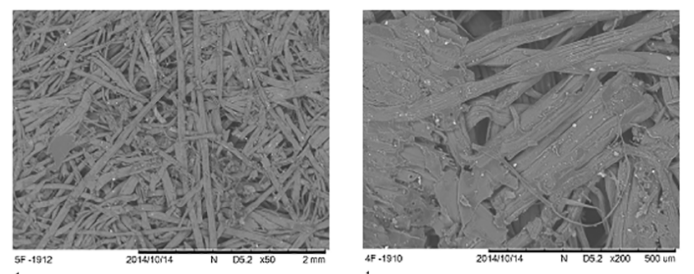

(e)

(f)

Figure 3. SEM images: (a) treatment $A$, (b) treatment $B$, (c) treatment C, (d) treatment D, (e) treatment $\mathrm{E}$ at $\times 50$ and (f) treatment $\mathrm{D}$ at $\times 200$ of magnification.
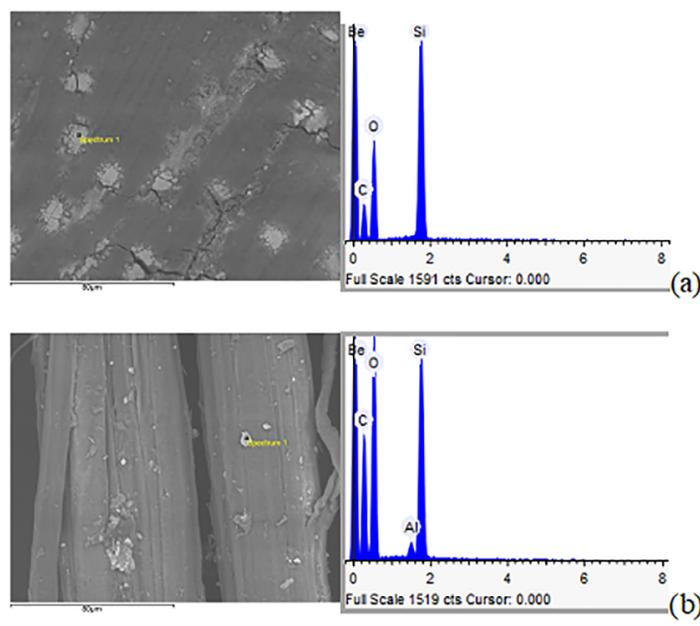

Figure 4. EDS obtained for (a) sugarcane bagasse and (b) Malva fibre $\mathrm{X}$-ray densitometry was carried out based on a set of ten samples for each Treatment. Table 3 shows the mean density for all treatments.

have been found by Belini et al. ${ }^{19}$, in panels produced with different percentages of eucalyptus wood and sugarcane bagasse. Some plants species can absorb silicon from the soil solution in the form of $\mathrm{H}_{4} \mathrm{SiO}_{4}$, which is commonly found at concentrations that range from 0.1 to $0.6 \mathrm{mM}$ at the $\mathrm{pH}$ levels found in most agricultural soils ${ }^{35}$.

Figure 5 shows the X-ray densitometry for Treatment A (a) and Treatment B (b). Filho et al. ${ }^{36}$ have investigated
Table 3. Mean density obtained via X-ray densitometry.

\begin{tabular}{cc}
\hline Treatments & Mean density $\left(\mathrm{Kg} \cdot \mathrm{m}^{-3}\right)$ \\
\hline $\mathrm{A}(100 \mathrm{P})$ & $584 \pm 106$ \\
$\mathrm{~B}(75 \mathrm{P} / 25 \mathrm{M})$ & $596 \pm 99$ \\
$\mathrm{C}(50 \mathrm{P} / 50 \mathrm{M})$ & $550 \pm 69$ \\
$\mathrm{D}(25 \mathrm{P} / 75 \mathrm{M})$ & $582 \pm 62$ \\
$\mathrm{E}(100 \mathrm{M})$ & $603 \pm 76$ \\
\hline
\end{tabular}

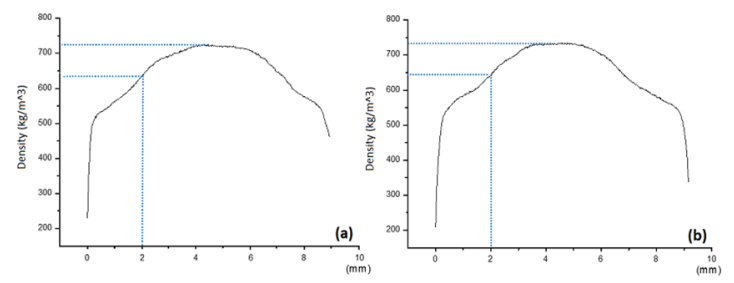

Figure 5. Profile densitometry by X-ray densitometry: (a) Treatment A and (b) Treatment B

MDF panels via X-ray densitometry, obtaining a type M profile, which indicates the presence of higher density at the outer layers. This profile is common for X-ray densitometry analyses in MDF panels produced with eucalyptus wood and another forestry species. In the present work, the profile found is inverse to the typical one for MDF, showing higher density for the core region. A slight increase in density was identified for treatment B, in which $25 \%$ of Malva fibres are incorporated.

\section{Conclusions}

All particleboards were classified as medium density panels based on the Brazilian, Canadian and American standards. The thermal treatment performed in Pinus wood makes the panel more hydrophobic. Treatment A, consisted of $100 \%$ of Pinus wood, achieved lower levels of thickness swelling at $2 \mathrm{~h}$ and $24 \mathrm{~h}$. In contrast, treatment $\mathrm{E}$, made with $100 \%$ of Malva fibres, achieved higher thickness swelling values, however those at $24 \mathrm{~h}$ did not achieve the standard requirements. All treatments reached the minimum flexural strength level, in contrast, the elastic moduli of the panels did not achieve the standard requirements. The presence of silica content in sugarcane and Malva fibres was identified by SEM and EDS, being attributed to the plant absorption in soil. X-ray densitometry revealed higher density in the core material. The incorporation of Malva fibres also contributes to increase the density of the sandwich panels. Tukey test demonstrated that both flexural strength and modulus responses for all treatments was statistically similar. For this reason, Treatment B, consisted of $75 \%$ of Pinus taeda wood and $25 \%$ of Malva fibres, demonstrated to be a promising hybrid particleboard, combining strength, low-cost and lower thickness swelling values. 


\section{References}

1. Kusumah SS, Umemura K, Guswenrivo I, Yoshimura T, Kanayama K. Utilization of sweet sorghum bagasse and citric acid for manufacturing of particleboard II: influences of pressing temperature and time on particleboard properties. Journal of Wood Science. 2017;63(2):161-172.

2. Saari N, Hashim R, Sulaiman O, Hiziroglu S, Sato M, Sugimoto T. Properties of steam treated binderless particleboard made from oil palm trunks. Composites Part B: Engineering. 2014;56:344349.

3. Li R, Lan C, Wu Z, Huang T, Chen X, Liao Y, et al. A novel particleboard using unsaturated polyester resin as a formaldehyde-free adhesive. Construction and Building Materials. 2017;148:781-788.

4. Yang F, Fei B, Wu Z, Peng L, Yu Y. Selected Properties of Corrugated Particleboards Made from Bamboo Waste (Phyllostachys edulis) Laminated with Medium-Density Fiberboard Panels. BioResources. 2014;9(1):1085-1096.

5. Moreno DDP, Saron C. Low-density polyethylene waste/recycled wood composites. Composite Structures. 2017;176:1152-1157.

6. Mendes RF, Mendes LM, Abranches RAS, Santos RC, Guimarães Júnior JB. Painéis aglomerados produzidos com bagaço de cana em associação com madeira de eucalipto. Scientia Florestalis. 2010;38(86):285-295

7. Santos RC, Mendes LM, Mori FA, Mendes RF. Chapas de partículas aglomeradas produzidas a partir de resíduos gerados após a extração do óleo da madeira de candeia (Eremanthus erythropappus). Scientia Florestalis. 2009;37(84):437-446.

8. Barros Filho RM. Painéis aglomerado a base de bagaço de cana-de-açúcar e resinas uréia formaldeído e melamina formaldeído. [Dissertation]. Ouro Preto: Federal University of Ouro Preto; 2009.

9. Brazil. Companhia Nacional de Abastecimento (CONAB). $A$ geração termoelétrica com a queima do bagaço de cana-deaçúcar no Brasil - Análise do Desempenho da Safra 2009-2010. Brasília: CONAB; 2011. 160 p.

10. Dantas Filho PL. Análise de custos na geração de energia com bagaço de cana-de-açúcar: um estudo de caso em quatro plantas em São Paulo. [Dissertation]. São Paulo: São Paulo University; 2009.

11. Silva AJP, Lahr FAR, Christoforo AL. Bagaço de cana pode virar painel OSB. Revista da Madeira. 2010;122(3):4p.

12. Basqueroto CH. Cogeração de energia elétrica com bagaço de cana-de-açúcar compressado (briquete). [Graduation research]. Araçatuba: Faculty of Technology of Araçatuba; 2010.

13. Belini UL. Caracterização tecnológica de painés de fibras da madeira de eucalipto, Eucalyptus grandis, e de particulas do bagaço do colmo de cana-de-açucar, Saccharum sp. [Thesis]. Piracicaba: São Paulo University; 2012.

14. Moura LF, Brito JO, Silva Júnior FG. Effect of thermal treatment on the chemical characteristics of wood from Eucalyptus grandis W. Hill ex Maiden under different atmospheric conditions. Cerne. 2012;18(3):449-455.
15. Esteves B, Graça J, Pereira H. Extractive composition and summative chemical analysis of thermally treated Eucalyptus wood". Holzforschung. 2008;62(3):344-351.

16. Pétrissans M, Gérardin P, El Bakali I, Serraj M. Wettability of heat-treated wood. Holzforschung. 2003;57(3):301-307.

17. Wahl P, Simonaho SP, Pakarinen T, Silvennoinen R. Effect of heat-treatment on scattering of laser light from wood grains. Holz als Roh- und Werkstoff. 2004;62(5):343-345.

18. Bonigut J, Krug D, Stephani B. Properties of thermally modified medium-density fibreboards. Holzforschung. 2012;66(1):79-83.

19. Belini UL, Tomazello Filho M, Louzada JLPC, Rodrigues JC. Aspectos anatômicos e tecnológicos de painéis confeccionados com fibras de eucalipto e cana-de-açúcar. Cerne. 2010;16(Suppl):48-52.

20. Brazilian Technical Standards Association (ABNT). ABNT NBR 15316-3 - Chapas de fibras de média densidade - Parte 3: Método de ensaio. Rio de Janeiro: ABNT; 2006.

21. Iwakiri S, Trianoski R, Cunha AB, Castro VG, Braz RL, VillasBôas BT, et al. Evaluation of the quality of particleboard panels manufactured with wood from Sequoia sempervirens and Pinus taeda. Cerne. 2014;20(2):209-216.

22. Silva MR, Fiorelli J, Nascimento MF, Lahr FAR, Salvastano Junior H. Painéis sustentáveis a base de fibra de malva, madeira termorretificada e bagaço de cana-de-açúcar. In: Anais do $1^{\circ}$ Congresso Luso-Brasileiro de Materiais de Construção Sustentáveis (CLB - MCS); 2014 Mar 5-7; Guimarães, Portugal.

23. Yildiz S, Gezer ED, Yildiz UC. Mechanical and chemical behavior of spruce wood modified by heat. Building and Environment. 2006;41(12):1762-1766.

24. Brazilian Technical Standards Association (ABNT). ABNTNBR 14810-1 - Painéis de partículas de média densidade - Parte 1: Terminologia. Rio de Janeiro: ABNT; 2013.

25. Murata K, Watanabe Y, Nakano T. Effect of Thermal Treatment of Veneer on Formaldehyde Emission of Poplar Plywood. Materials. 2013;6(2):410-420

26. Brazilian Technical Standards Association (ABNT). ABNT NBR 14810-2 - Painéis de partículas de média densidade Parte 2: Requisitos e métodos de ensaio. Rio de Janeiro: ABNT; 2013.

27. Commercial Standard. Matformed wood particleboard. CS 236-66. Washington; 1968.

28. American National Standard Institute. ANSI A 208.1-1 Particleboard. Gaithersburg: Composite Panel Association; 1999.

29. Kartal SN, Hwang WJ, Imamura Y. Water absorption of borontreated and heat-modified wood. Journal of Wood Science. 2007;53(5):454-457.

30. Silva MS, Machado GO, Brito JO, Calil Junior C. Strength and stiffness of thermally rectified Eucalyptus wood under compression. Materials Research. 2013;16(5):1077-1083.

31. Fiorelli J, Sartori DL, Cravo JCM, Savastano Junior H, Rossignolo JA, Nascimento MF, et al. Sugarcane bagasse and castor oil polyurethane adhesive-based particulate composite. Materials Research. 2013;16(2):439-446.

32. Murata K, Watanabe Y, Nakano T. Effect of Thermal Treatment on Fracture Properties and Adsorption Properties of Spruce Wood. Materials. 2013;6(9):4186-4197. 
33. Bertolini MS. Emprego de resíduos de Pinus sp tratado com preservante CCB na produção de chapas de partículas homogêneas utilizando resina poliuretana à base de mamona. [Dissertation]. São Carlos: São Paulo University; 2011.

34. Nascimento MF (2014). "Artificial weathering degradation of high density particleboards made with wood residues treated with CCA and CCB preservatives". 2014. 36 p. Postdoctoral Report. São Paulo University, Pirassununga, Brazil.
35. Knight CTG, Kinrade SD. A primer on the aqueous chemistry of silicon. In: Datnoff LE, Snyder GH, Korndörfer GH, eds. Silicon in Agriculture, Volume 8. Amsterdam: Elsevier Science; 2001. p. 57-84.

36. Tomazello Filho M, Belini UL, Oliveira JTS, Gonçalves FG. Avaliação tecnológica da madeira e de painéis MDF de eucalipto por densitometria de raios X. Madeira: Arquitetura \& Engenharia. 2010;11(27):45-58. 